•生物编目・

\title{
西沙群岛植物的订正与增补
}

\author{
邓双文 ${ }^{1,2}$ 王发国 ${ }^{1}$ 刘俊芳 ${ }^{1,2}$ 邢福武 ${ }^{*}$ \\ 1 (中国科学院华南植物园, 广州 510650) \\ 2 (中国科学院大学生命科学学院, 北京 100049)
}

\section{Revision and supplement to plants from Xisha Islands, China}

\author{
Shuangwen Deng ${ }^{1,2}$, Faguo Wang ${ }^{1}$, Junfang Liu ${ }^{1,2}$, Fuwu Xing ${ }^{1 *}$ \\ 1 South China Botanical Garden, Chinese Academy of Sciences, Guangzhou 510650 \\ 2 College of Life Sciences, University of Chinese Academy of Sciences, Beijing 100049
}

西沙群岛 $\left(15^{\circ} 46^{\prime}-17^{\circ} 08^{\prime} \mathrm{N}, 111^{\circ} 11^{\prime}-112^{\circ} 54^{\prime} \mathrm{E}\right)$ 位于南海的西北部、海南岛东南部。由永乐群岛和 宣德群岛组成, 共有 22 个大小不一的岛屿、7个沙洲 和10多个暗礁暗滩, 总陆地面积约7.6047 $\mathrm{km}^{2}$, 是 南海诸岛中陆地面积最大、植物资源最丰富的群 岛。除石岛及高尖石外, 西沙群岛的岛屿均由珊瑚 礁在近6,000年来逐渐发育形成(卢演俦等，1979), 岛上的植物均是从邻近地区通过海流、鸟类和风传 播而来。我国植物学家对西沙群岛的植物多样性进 行了 5 次规模较大的调查(Chang, 1948; 广东省植物 研究所西沙群岛植物调查队, 1977; 钟义, 1990; 邢 福武等, 1993a, b; 海南省海洋厅海南省海岛资源综 合调查领导小组办公室, 1996; 张浪等, 2011; 童毅 等, 2013), 其中童毅等(2013)对西沙群岛有植物分 布的所有岛屿及沙洲均进行了调查, 共统计到高等 植物396种, 其中栽培植物176种, 野生植物220种。

西沙群岛远离大陆, 各个岛屿间具有天然的地 理隔离, 是研究岛屿生物地理的理想地点。近年来, 关于该地区珊瑚礁岛植物传播、传粉网络等方面的 研究逐渐开展。虽然已有多次较全面的调查, 但作 者在2016年和2017年的调查中仍发现一些新记录 种。在对西沙群岛植物区系进行深入研究后发现, 已有研究多是直接参考更早发表的名录, 导致之前 调查中鉴定错误的物种一直没有得到订正。我们在 文中对其进行了订正, 并对西沙群岛植物名录进行 了更新, 以期为西沙群岛植物区系的研究提供基础
性资料。

\section{1 方法}

于2016年6月、12月及2017年4月对西沙群岛中 的永兴岛、石岛、东岛、琛航岛和广金岛进行了实 地调查，共采集标本 250 号，拍摄照片 4,000 余张; 查阅并重新鉴定了华南植物园标本馆及中山大学 植物标本馆馆藏的 500 余号西沙群岛植物标本。

\section{2 结果}

结果表明, 西沙群岛野生维管植物共计 47 科 137属193种(附录1)。新增西沙群岛新记录植物5 种, 均为野生植物(详细的物种描述见附录 2); 从历史 标本鉴定结果来看, 有22种植物被错误鉴定为其他 名称, 其中圆叶黄花稔(Sida alnifolia var. orbiculata S. Y. Hu) 和鲫鱼草(Eragrostis tenella (L.) Beauv. ex Roem. et Schult.)有两个鉴定错误的结果, 而黄细心 (Boerhavia diffusa L.) 除有个别标本鉴定错误外，尚 有鉴定准确的个体。综上，共有23种应从以前的名 录中予以剔除(详细的物种描述见附录 2 ); 另有 10 种列为存疑。

\section{1 分类群增补}

(1)匍匐黄细心(紫茉莉科 Nyctaginaceae) (图1A, $\mathrm{B}, \mathrm{C})$

Boerhavia repens L., Sp. Pl. 1: 3. 1753; Fl. China 5: 433-434. 2003. 
(2)小刀豆(蝶形花科 Papilionaceae) (图1D, E, F)

Canavalia cathartica Thou., J. Bot. Agric. 1: 81. 1813; Fl. China 10: 198-199. 2010.

(3)落地豆(蝶形花科 Papilionaceae) (图 1G, H, I)

Rothia indica (L.) Druce, Bot. Exch. Club Soc. Brit. Isles 3: 423. 1914; Fl. China 10: 118. 2010.

(4)矮灰毛豆(蝶形花科 Papilionaceae) (图1J, K, L)

Tephrosia pumila (Lam.) Pers., Syn. Pl. 2(2): 330. 1807; Fl. China 10: 190-193. 2010.

(5)小花宽叶十万错(爵床科 Acanthaceae) (图1M, $\mathrm{N}, \mathrm{O})$

Asystasia gangetica subsp. micrantha (Nees) Ensermu, Proc. XIII Plen. Meet. AETFAT Zomba Malawi: 1: 343. 1994; Fl. China 19: 437-438. 2011.

\section{2 分类群学名订正}

(1)皱果苋

Amaranthus viridis L. - A. caudatus auct. non L.: 我国西沙群岛的植物和植被: 78. 1977.

(2)黄细心

Boerhavia diffusa L. - B. chinensis auct. non (L.) Rottb.: 我国西沙群岛的植物和植被: 78-79. 1977.

(3)匍匐黄细心

Boerhavia repens L. - B. diffusa auct. non L.: H. T. Chang in Sunyatsenia, 7(1-2), 80-81. 1948; 我 国西沙群岛的植物和植被: 78-79.1977.

(4)圆叶黄花稔

Sida alnifolia var. orbiculata $\mathrm{S}$. $\mathrm{Y}$. $\mathrm{Hu}-S$. chinensis auct. non Retz.: F. W. Xing et al in J. Plant Resour. Environ. 2(3), 4. 1993.—S. parvifolia auct. non DC.: 我国西沙群岛的植物和植被: 68, 84. 1977.

(5)长梗黄花稔

Sida cordata (Burm. f.) Borss. $\longrightarrow S$. mysorensis auct. non Wight et Arn.: 我国西沙群岛的植物和植 被: 84. 1977.

(6)猩猩草

Euphorbia cyathophora Murr. $-E$. heterophylla auct. non L.: 我国西沙群岛的植物和植被: 84-85. 1977.

(7)匍匐大戟

Euphorbia prostrata Aiton-E. heyneana auct. non Spreng.: H. T. Chang in Sunyatsenia, 7(1-2),
82. 1948.

(8)苦味叶下珠

Phyllanthus amarus Schumach. et Thonn. $-P$. urinaria auct. non L.: H. T. Chang in Sunyatsenia, 7(1-2), 82. 1948.

(9)刺果苏木

Caesalpinia bonduc (L.) Roxb.-C. minax auct. non Hance: 我国西沙群岛的植物和植被： 88 . 1977.

(10)海刀豆

Canavalia rosea (Sw.) DC.—Mucuna hainanensis auct. non Hayata: 我国西沙群岛的植物和植 被: 90. 1977.

(11)笔管榕

Ficus subpisocarpa Gagnep._-F. virens auct. non Aiton: 我国西沙群岛的植物和植被: 92. 1977.

(12)光叶丰花草

Spermacoce remota Lam.-S. pusilla auct. non Wall.: Y. Tong in Biodivers. Sci., Appendix 1: 9. 2013.

(13)海人树

Suriana maritima L._Scaevola hainanensis auct. non Hance: H. T. Chang in Sunyatsenia, 7(1-2), 84. 1948.

(14)苦蘵

Physalis angulata L. P. minima auct. non L.: 我国西沙群岛的植物和植被: 98.1977 。

(15)管花薯

Ipomoea violacea $\mathrm{L}$. - I. alba auct. non L.: $\mathrm{H}$. T. Chang in Sunyatsenia, 7(1-2), 85-86. 1948.

(16)蜂巢草

Leucas aspera (Willd.) Link-L. zeylanica auct. non (L.) R. Brown: 我国西沙群岛的植物和植 被: 102. 1977.

\section{(17)佛焰苞飘拂草}

Fimbristylis spathacea Roth-F. dichotoma auct. non (L.) Vahl: 我国西沙群岛的植物和植被: 106. 1977.

(18)龙爪茅

Dactyloctenium aegyptium (L.) Willd.—Arthraxon hispidus var. cryptatherus auct. non (Hack.) Honda: 我国西沙群岛的植物和植被: 106. 1977. 


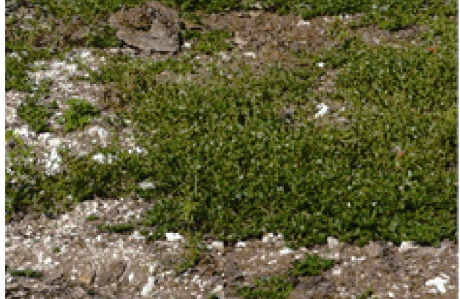

A


G


M

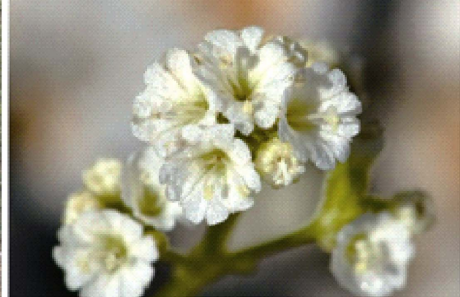

B
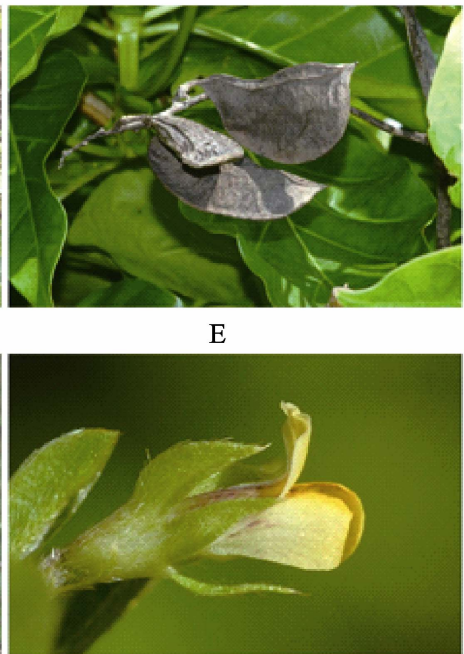

$\mathrm{H}$

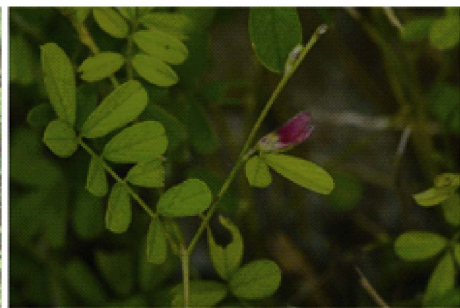

$\mathrm{K}$



$\mathrm{N}$



C


I

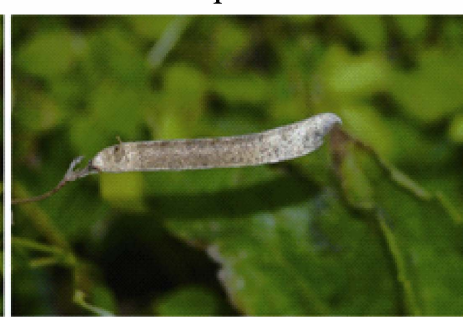

$\mathrm{L}$

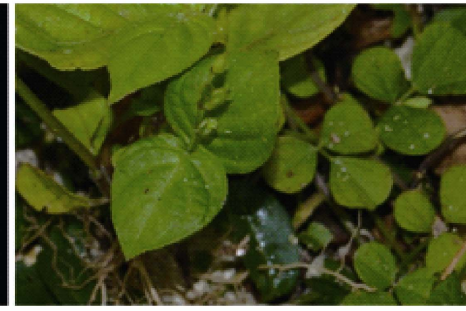

$\mathrm{O}$

图1 西沙群岛5种新记录植物。A-C: 匍匐黄细心; D-F: 小刀豆; G-I: 落地豆; J-L: 矮灰毛豆; M-O: 小花宽叶十万错。

Fig. 1 Five new recorded species from Xisha Islands. A-C, Boerhavia repens L.; D-F, Canavalia cathartica Thou.; G-I, Rothia indica (L.) Druce; J-L, Tephrosia pumila (Lam.) Pers.; M-O, Asystasia gangetica subsp. micrantha (Nees) Ensermu.

(19)毛臂形草

Brachiaria villosa (Lam.) A. Camus- $-B$. ramosa auct. non (L.) Stapf: 我国西沙群岛的植物和 植被: 108. 1977 。

(20)狗牙根

Cynodon dactylon (L.) Pers__Eremochloa ophiuroides auct. non (Munro) Hack.: 我国西沙群岛
的植物和植被: 108. 1977.

\section{(21) 鲫鱼草}

Eragrostis tenella (L.) Beauv. ex Roem. et Schult.—E. amabilis auct. non (L.) Wight \& Arn.: H. T. Chang in Sunyatsenia, 7(1-2), 85-86. 1948. E. ciliata auct. non (Roxb.) Nees: 我国西沙群 岛的植物和植被: 110.1977. 


\section{(22)圆果雀稗}

Paspalum scrobiculatum var. orbiculare (G. Forst.) Hack. $\longrightarrow$. longifolium auct. non Roxb.: 我 国西沙群岛的植物和植被: 110. 1977.

另外, 教僽(Tribulus terrestris L.)、虫豆(Cajanus volubilis (Blanco) Blanco)、西沙灰毛豆(Tephrosia luzonensis Vogel)、光枝木龙葵(Solanum merrillianum Liou)、龙葵(Solanum nigrum L.) 、知风飘拂草 (Fimbristylis eragrostis (Nees \& Meyen) Hance)、白 羊草(Bothriochloa ischaemum (L.) Keng)和海雀稗 (Paspalum vaginatum Swartz)等7种植物虽曾有记录, 但未见其馆藏标本, 且实地调查均未见到, 又因在 西沙群岛均有与其十分类似的种类, 故暂列为存 疑。油楠(Sindora glabra Merr. ex de Wit.)、华南云 实 (Caesalpinia crista L.) 和苦槛蓝 (Pentacoelium bontioides Siebold \& Zucc) 3种植物的凭证标本为幼 苗, 作者认为鉴定可信度很低, 且在 3 次实地调查 中均未见到, 也暂列为存疑。

\section{3 讨论}

西沙群岛植物区系的动态变化与人类活动的 关系密切。该地区植被的自然发生发展过程十分缓 慢, 所有植物的果实、种子及营养体均是通过海流、 风和鸟类由邻近区域传播而来, 且大多数种类无法 定植, 只有少数适应海边高盐度环境的种类才能慢 慢发展起来, 最终通过自然途径传播并发展起来的 原生物种仅有40多种。1947年4月, 张宏达先生首次 对该地的植物资源进行了科学调查(赵焕庭, 1996), 记录了西沙群岛野生维管植物35种(Chang, 1948), 当时西沙群岛人类活动少, 植物种类亦少。1974年, 华南植物研究所调查队对西沙群岛植被进行了深 入调查(赵焕庭, 1996), 记录野生维管植物166种。植 物种类的增加除了与调查深入有关, 更与日益频繁 的人类活动相吻合。在其后的调查中, 仍有植物不 断被记录, 但大多只见于建设力度最大的永兴岛。 从近几次调查结果来看, 西沙群岛的植物种类组成 已趋于稳定, 但是随着建设力度的加大, 未来将还 会有植物被陆续引入。在本次调查中, 落地豆属 (Rothia) 和十万错属(Asystasia)为西沙群岛新记录属, 发现新记录植物 5 种。其中矮灰毛豆、落地豆和小 花宽叶十万错生于居民区附近, 极可能是其种子混 于土壤中被引入; 而匍匐黄细心和小刀豆生于海岸
附近，应该是通过鸟类和海流传播而来的原生物种。

我们通过对1947年、1974年及1992年3次调查 的馆藏标本的复核，订正了鉴定错误的标本。共发 现鉴定错误的植物 23 种, 占西沙群岛野生植物总数 的 $10 \%$ 。对鉴定错误原因进行分析发现，其中大部 分属于疑难属的鉴定错误，如大戟属(Euphorbia)、 黄细心属(Boerhavia)、黄花稔属(Sida)、马唐属(Digitaria)、画眉草属(Eragrostis)和雀稗属(Paspalum), 且同一种植物在历次调查中被鉴定为多个不同的 物种。前人对西沙群岛的植物区系地理已有深入研 究, 在此不再赘述, 但有两点值得注意, 一是在原 有资料中, 西沙群岛为小草海桐(Scaevola hainanensis Hance)分布的南界，修订后应北移至海南岛; 二是西沙群岛的植物区系与邻近地区的相似性很 高, 前人指出西沙群岛植物区系中仅有喙荚云实 (Caesalpinia minax Hance)和小草海桐等不见于马 来西亚、印度尼西亚和菲律宾, 根据修订结果, 其 相似性也会提高。

\section{参考文献}

Chang HT (1948) The vegetation of the Paracel Islands. Sunyatsenia, 7(1-2), 75-88.

Department of Ocean of Hainan Province, The Head Office of Comprehensive Investigation of Marine Island Resources in Hainan Province (1996) The Research Report of Comprehensive Investigation of Marine Island Resources in Hainan Province. China Ocean Press, Beijing. (in Chinese) [海南省 海洋厅, 海南省海岛资源综合调查领导小组办公室 (1996) 海南省海岛资源综合调查研究报告. 海洋出版社, 北京.]

Lu YC, Yang XH, Jia RF (1979) Quarternary biological sediments in the Xisha Archipelago, China and a discussion on the age of island-formation. Geochemica, (2), 93-102. (in Chinese with English abstract) [卢演俦, 杨学昌, 贾蓉芬 (1979) 我国西沙群岛第四纪生物沉积物及成岛时期的探 讨. 地球化学, (2), 93-102.]

Paracel Islands Plant Expedition of Guangdong Institute of Botany (1977) Plants and Vegetation on Xisha Islands of China. Science Press, Beijing. (in Chinese) [广东省植物研 究所西沙群岛植物调查队 (1977) 中国西沙群岛的植物 和植被. 科学出版社, 北京.]

Tong Y, Jian SG, Chen Q, Li YL, Xing FW (2013) Vascular plant diversity of the Paracel Islands, China. Biodiversity Science, 21, 364-374. (in Chinese with English abstract) [童 毅, 简曙光, 陈权, 李玉玲, 邢福武 (2013) 中国西沙群 岛植物多样性. 生物多样性, 21, 364-374.]

Xing FW, Li ZX, Ye HG, Chen BH, Wu DL (1993a) A study on the floristic plant geography of Xisha Islands, South 
China. Tropical Geography, 13(3), 250-257. (in Chinese with English abstract) [邢福武, 李泽贤, 叶华谷, 陈炳辉, 吴德邻 (1993a) 我国西沙群岛植物区系地理的研究. 热 带地理, 13(3), 250-257.]

Xing FW, Wu DL, Li ZX, Ye HG, Chen BH (1993b) Investigation of plant resources in Xisha Islands. Journal of Plant Resources and Environment, 2(3), 1-6. (in Chinese with English abstract) [邢福武, 吴德邻, 李泽贤, 叶华谷, 陈炳 辉 (1993b) 西沙群岛植物资源调查. 植物资源与环境, 2(3), 1-6.]

Zhang L, Liu ZW, Jiang DQ (2011) Ecological investigation of the vegetation in the Paracel Islands. Chinese Agricultural Science Bulletin, 27(14), 181-186. (in Chinese with English abstract) [张浪, 刘振文, 姜殿强 (2011) 西沙群岛植被生 态调查. 中国农学通报, 27(14), 181-186.]

Zhao HT (1996) History of expeditions to Xisha Islands. Geographical Reseach, 15(4), 55-65. (in Chinese with English abstract) [赵焕庭 (1996) 西沙群岛考察史. 地理研究, 15(4), 55-65.]

Zhong Y (1990) The plant resources investigation of Paracel Islands, Hainan. Journal of Hainan Normal University, 3(1), 48-65. (in Chinese with English abstract) [钟义 (1990) 海 南省西沙群岛植物资源考察. 海南师范学院学报, 3(1), 48-65.]

(责任编委：李振宇＼cjkstart责任编辑：黄祥忠)

\section{附录 Supplementary Material}

\section{附录1 西沙群岛野生植物名录}

Appendix 1 The wild plant checklist of Xisha Islands, China http://www.biodiversity-science.net/fileup/PDF/2017066-1.pdf

\section{附录2 西沙群岛增补及订正植物种类的描述}

Appendix 2 Description of plants supplemented and revised of Xisha Islands, China http://www.biodiversity-science.net/fileup/PDF/2017066-2.pdf 
邓双文, 王发国, 刘俊芳, 邢福武. 西沙群岛植物的订正与增补. 生物多样性, 2017, 25 (11): 1246-1250.

http://www.biodiversity-science.net/CN/10.17520/biods.2017066

\section{附录1 西沙群岛野生植物名录}

Appendix 1 The wild plant checklist of Xisha Islands, China

科按照哈钦松系统排序，属种按照拉丁学名字母排序; 标本为作者所复核的标本，其中标注“-”意为未见其标本。




邓双文, 王发国, 刘俊芳, 邢福武. 西沙群岛植物的订正与增补. 生物多样性, 2017, 25 (11): 1246-1250.

http://www.biodiversity-science.net/CN/10.17520/biods.2017066

\begin{tabular}{|c|c|c|c|}
\hline 科名 Family & 物名 Species & 标本 Specimen & 文献 Reference \\
\hline & & 西沙队 3363 & \\
\hline & 青葙 Celosia argentea L. & 西沙队 3302 & 广东省植物研究所西沙群岛植物 \\
\hline & & & 调查队, 1977 \\
\hline & 银花苋 Gomphrena celosioides Mart. & 西沙队 3278 & 广东省植物研究所西沙群岛植物 \\
\hline & & 李泽贤等 5544 & 调查队, 1977 \\
\hline 薮藜科 Zygophyllaceae & 大花祅藜 Tribulus cistoides L. & 西沙队 3228 & 钟义, 1990 \\
\hline \multirow[t]{2}{*}{ 千屈菜科 Lythraceae } & 水芫花 Pemphis acidula J. R. Forst. \& G. Forst. & 西沙队 3365 & 广东省植物研究所西沙群岛植物 \\
\hline & & 李泽贤等 5551 & 调查队, 1977 \\
\hline \multirow[t]{10}{*}{ 紫莱莉科 Nyctaginaceae } & 黄细心 Boerhavia diffusa L. & 西沙队 3260 & Chang, 1948 \\
\hline & & 李泽贤等 5512 & \\
\hline & 直立黄细心 Boerhavia erecta L. & 西沙队 3227 & 广东省植物研究所西沙群岛植物 \\
\hline & & & 调查队, 1977 \\
\hline & 匍匐黄细心 Boerhavia repens L. & 张宏达 4113 & 新记录 \\
\hline & & 西沙队 3210 & \\
\hline & & 李泽贤等 5426 & \\
\hline & 抗风桐 Pisonia grandis R. Br. & 张宏达 4103 & Chang, 1948 \\
\hline & & 西沙队 3235 & \\
\hline & & 李泽贤等 5490 & \\
\hline \multirow[t]{2}{*}{ 西番莲科 Passifloraceae } & 龙珠果 Passiflora foetida L. & 西沙队 3321 & 广东省植物研究所西沙群岛植物 \\
\hline & & 李泽贤等 5390 & 调查队, 1977 \\
\hline 使君子科 Combretaceae & 榄李 Lumnitzera racemosa Willd. & - & 童毅等, 2013 \\
\hline \multirow[t]{2}{*}{ 藤黄科 Guttiferae } & 红厚壳 Calophyllum inophyllum L. & 西沙队 3351 & 广东省植物研究所西沙群岛植物 \\
\hline & & 李泽贤等 5453 & 调查队, 1977 \\
\hline \multirow[t]{10}{*}{ 椴树科 Tiliaceae } & 甜麻 Corchorus aestuans L. & 西沙队 3349 & 广东省植物研究所西沙群岛植物 \\
\hline & & 李泽贤等 5526 & 调查队, 1977 \\
\hline & 粗齿刺蒴麻 Triumfetta grandidens Hance & 李泽贤等 5507 & 邢福武, 1993 \\
\hline & 铺地刺蒴麻 Triumfetta procumbens G. Forst. & 张宏达 4129 & Chang, 1948 \\
\hline & & 西沙队 3279 & \\
\hline & & 李泽贤等 5425 & \\
\hline & 刺龩麻 Triumfetta rhomboidea Jacq. & 西沙队 3316 & 广东省植物研究所西沙群岛植物 \\
\hline & & 李泽贤等 5514 & 调查队, 1977 \\
\hline & 蛇婆子 Waltheria indica L. & 西沙队 3200 & 广东省植物研究所西沙群岛植物 \\
\hline & & 李泽贤等 5375 & 调查队, 1977 \\
\hline \multirow[t]{10}{*}{ 锦葵科 Malvaceae } & 磨盘草 Abutilon indicum (L.) Sweet & 西沙队 3241 & 广东省植物研究所西沙群岛植物 \\
\hline & & 李泽贤等 5397 & 调查队, 1977 \\
\hline & 泡果苟 Herissantia crispa (L.) Brizicky & 西沙队 3232 & 广东省植物研究所西沙群岛植物 \\
\hline & & 李泽贤等 5399 & 调查队, 1977 \\
\hline & 赛葵 Malvastrum coromandelianum (L.) Garcke & 张宏达 4177 & Chang, 1948 \\
\hline & & 西沙队 3250 & \\
\hline & 黄花稔 Sida acuta Burm. f. & 西沙队 3231 & 广东省植物研究所西沙群岛植物 \\
\hline & & 李泽贤等 5433 & 调查队, 1977 \\
\hline & 圆叶黄花稔 Sida alnifolia var. orbiculata S. Y. Hu & 西沙队 3259 & 广东省植物研究所西沙群岛植物 \\
\hline & & 西沙队 3328 & 调查队, 1977 \\
\hline
\end{tabular}


邓双文, 王发国, 刘俊芳, 邢福武. 西沙群岛植物的订正与增补. 生物多样性, 2017, 25 (11): 1246-1250.

http://www.biodiversity-science.net/CN/10.17520/biods.2017066

\begin{tabular}{|c|c|c|c|}
\hline 科名 Family & 物名 Species & 标本 Specimen & 文献 Reference \\
\hline & & 李泽贤等 5415 & \\
\hline & & 李泽贤等 5489 & \\
\hline & 长梗黄花稔 Sida cordata (Burm. f.) Borss. Waalk. & 西沙队 3230 & 钟义, 1990 \\
\hline & 心叶黄花稔 Sida cordifolia L. & 西沙队 3310 & 广东省植物研究所西沙群岛植物 \\
\hline & & 李泽贤等 5510 & 调查队, 1977 \\
\hline & 白背黄花稔 Sida rhombifolia L. & 李泽贤等 5435 & 广东省植物研究所西沙群岛植物 \\
\hline & & & 调查队, 1977 \\
\hline & 桐棉 Thespesia populnea (L.) Sol. ex Corrêa & 西沙队 3404 & 广东省植物研究所西沙群岛植物 \\
\hline & & 李泽贤等 5554 & 调查队, 1977 \\
\hline \multirow[t]{20}{*}{ 大戟科 Euphorbiaceae } & 铁苋菜 Acalypha australis L. & - & 钟义, 1990 \\
\hline & 热带铁苋菜 Acalypha indica L. & - & 童毅等, 2013 \\
\hline & 麻叶铁苋菜 Acalypha lanceolata Willd. & 李泽贤等 5455 & 邢福武等, 1993 \\
\hline & 海滨大戟 Euphorbia atoto G. Forst. & 西沙队 3275 & Chang, 1948 \\
\hline & & 李泽贤等 5436 & \\
\hline & 通奶草 Euphorbia hypericifolia L. & 西沙队 3326 & 广东省植物研究所西沙群岛植物 \\
\hline & & & 调查队, 1977 \\
\hline & 匍匐大戟 Euphorbia prostrata Aiton & 张宏达 4098 & Chang, 1948 \\
\hline & & 西沙队 3252 & \\
\hline & & 李泽贤等 5413 & \\
\hline & & 李泽贤等 $5413 \mathrm{~A}$ & \\
\hline & 千根草 Euphorbia thymifolia L. & 邓双文 137 & 广东省植物研究所西沙群岛植物 \\
\hline & & & 调查队, 1977 \\
\hline & 小果木 Micrococca mercurialis (L.) Benth. & 邓双文 153 & 童毅等, 2013 \\
\hline & 地杨桃 Microstachys chamaelea (L.) Müll. Arg. & 西沙队 3311 & 广东省植物研究所西沙群岛植物 \\
\hline & & 李泽贤等 5488 & 调查队, 1977 \\
\hline & 苦味叶下珠 Phyllanthus amarus Schum. \& Thonn. & 张宏达 4120 & 新记录 \\
\hline & & 西沙队 3257 & \\
\hline & & 李泽贤等 5388 & \\
\hline & 艾堇 Sauropus bacciformis (L.) Airy Shaw & 周联选等 12430 & 童毅等, 2013 \\
\hline \multirow[t]{7}{*}{ 含羞草科 Mimosaceae } & 榼藤 Entada phaseoloides (L.) Merr. & 西沙队 3335 & 广东省植物研究所西沙群岛植物 \\
\hline & & 西沙队 3344 & 调查队, 1977 \\
\hline & 巴西含羞草 Mimosa diplotricha Wright & 李泽贤等 5373 & 钟义, 1990 \\
\hline & 无刺巴西含羞草 Mimosa diplotricha var. inermis (Adelb.) & - & 童毅等, 2013 \\
\hline & Alam et Yusof & & \\
\hline & 含羞草 Mimosa pudica L. & 西沙队 3317 & 广东省植物研究所西沙群岛植物 \\
\hline & & 李泽贤等 5518 & 调查队, 1977 \\
\hline \multirow[t]{7}{*}{ 苏木科 Caesalpiniaceae } & 刺果苏木 Caesalpinia bonduc (L.) Roxb. & 西沙队 3366 & 新记录 \\
\hline & & 李泽贤等 5446 & \\
\hline & 柄腺山扁豆 Chamaecrista pumila (Lam.) V. Singh & 李泽贤等 5472 & 邢福武等, 1993 \\
\hline & 望江南 Senna occidentalis (L.) Link & 西沙队 3285 & 广东省植物研究所西沙群岛植物 \\
\hline & & 李泽贤等 5459 & 调查队, 1977 \\
\hline & 决明 Senna tora (L.) Roxb. & 西沙队 3312 & 广东省植物研究所西沙群岛植物 \\
\hline & & & 调查队, 1977 \\
\hline
\end{tabular}


邓双文, 王发国, 刘俊芳, 邢福武. 西沙群岛植物的订正与增补. 生物多样性, 2017, 25 (11): 1246-1250.

http://www.biodiversity-science.net/CN/10.17520/biods.2017066

\begin{tabular}{|c|c|c|c|}
\hline 科名 Family & 物名 Species & 标本 Specimen & 文献 Reference \\
\hline \multirow[t]{31}{*}{ 蝶形花科 Papilionaceae } & 相思子 Abrus precatorius L. & 李泽贤等 5520 & 邢福武等, 1993 \\
\hline & \multirow[t]{2}{*}{ 链苒豆 Alysicarpus vaginalis (L.) DC. } & 西沙队 3300 & 广东省植物研究所西沙群岛植物 \\
\hline & & 李泽贤等 5505 & 调查队, 1977 \\
\hline & 蔓草虫豆 Cajanus scarabaeoides (L.) Thouars & 李泽贤等 5479 & 邢福武等, 1993 \\
\hline & \multirow[t]{3}{*}{ 海刀豆 Canavalia rosea (Sw.) DC. } & 西沙队 3244 & 广东省植物研究所西沙群岛植物 \\
\hline & & 西沙队 3405 & \multirow[t]{2}{*}{ 调查队, 1977} \\
\hline & & 李泽贤等 5386 & \\
\hline & 小刀豆 Canavalia cathartica Thou. & 邓双文 109 & 新记录 \\
\hline & \multirow[t]{2}{*}{ 猪屎豆 Crotalaria pallida Aiton } & 西沙队 3385 & 广东省植物研究所西沙群岛植物 \\
\hline & & 李泽贤等 5380 & 调查队, 1977 \\
\hline & \multirow[t]{2}{*}{ 三点金 Desmodium triflorum (L.) DC. } & 西沙队 3378 & 广东省植物研究所西沙群岛植物 \\
\hline & & 李泽贤等 5519 & 调查队, 1977 \\
\hline & \multirow[t]{2}{*}{ 疏花木蓝 Indigofera colutea (Burm. f.) Merr. } & 西沙队 3329 & 广东省植物研究所西沙群岛植物 \\
\hline & & 李泽贤等 5461 & 调查队, 1977 \\
\hline & 硬毛木蓝 Indigofera hirsuta L. & 李泽贤等 5506 & 邢福武等, 1993 \\
\hline & \multirow[t]{2}{*}{ 九叶木蓝 Indigofera linnaei Ali } & \multirow[t]{2}{*}{ 西沙队 3381} & 广东省植物研究所西沙群岛植物 \\
\hline & & & 调查队, 1977 \\
\hline & 刺荚木蓝 Indigofera nummulariifolia (L.) Livera ex & 李泽贤等 5513 & 邢福武等, 1993 \\
\hline & Alston & & \\
\hline & 小鹿蕉 Rhynchosia minima (L.) DC. & 李泽贤等 5528 & 邢福武等, 1993 \\
\hline & 刺田菁 Sesbania bispinosa (Jacq.) W. Wight & 李泽贤等 5480 & 邢福武等, 1993 \\
\hline & \multirow[t]{2}{*}{ 田菁 Sesbania cannabina (Retz.) Poir. } & 西沙队 3387 & \multirow[t]{2}{*}{ 钟义, 1990} \\
\hline & & 李泽贤等 5395 & \\
\hline & \multirow[t]{2}{*}{ 线毛槐 Sophora tomentosa L. } & 西沙队 3350 & 广东省植物研究所西沙群岛植物 \\
\hline & & 李泽贤等 5452 & 调查队, 1977 \\
\hline & 落地豆 Rothia indica (L.) Druce & 邓双文 131 & 新记录 \\
\hline & 矮灰毛豆 Tephrosia pumila (Lam.) Pers. & 邓双文 119 & 新记录 \\
\hline & \multirow[t]{2}{*}{ 灰毛豆 Tephrosia purpurea (L.) Pers. } & 西沙队 3239 & 广东省植物研究所西沙群岛植物 \\
\hline & & 李泽贤等 5420 & 调查队, 1977 \\
\hline & \multirow[t]{2}{*}{ 滨豇豆 Vigna marina (Burm.) Merr. } & 西沙队 3360 & 广东省植物研究所西沙群岛植物 \\
\hline & & 李泽贤等 5475 & 调查队, 1977 \\
\hline 榆科 Ulmaceae & 异色山黄麻 Trema orientalis (L.) Blume & - & 钟义, 1990 \\
\hline \multirow[t]{2}{*}{ 桑科 Moraceae } & \multirow[t]{2}{*}{ 笔管榕 Ficus subpisocarpa Gagnep. } & 西沙队 3234 & 广东省植物研究所西沙群岛植物 \\
\hline & & 李泽贤等 5474 & 调查队, 1977 \\
\hline 鼠李科 Rhamnaceae & 蛇藤 Colubrina asiatica (L.) Brongn. & 邓双文 159 & 童毅等, 2013 \\
\hline \multirow[t]{3}{*}{ 海人树科 Simaroubaceae } & \multirow[t]{3}{*}{ 海人树 Suriana maritima L. } & 张宏达 4119 & 广东省植物研究所西沙群岛植物 \\
\hline & & 西沙队 3243 & 调查队, 1977 \\
\hline & & 李泽贤等 5470 & \\
\hline 无患子科 Sapindaceae & 倒地铃 Cardiospermum halicacabum L. & 李泽贤等 5533 & 邢福武等, 1993 \\
\hline \multirow[t]{2}{*}{ 夹竹桃科 Apocynaceae } & \multirow[t]{2}{*}{ 海杧果 Cerbera manghas L. } & \multirow[t]{2}{*}{ 西沙队 3393} & 广东省植物研究所西沙群岛植物 \\
\hline & & & 调查队, 1977 \\
\hline \multirow[t]{2}{*}{ 茜草科 Rubiaceae } & \multirow{2}{*}{ 小牙草 Dentella repens (L.) J. R. Frost. \& G. Forst. } & 西沙队 3372 & 广东省植物研究所西沙群岛植物 \\
\hline & & 李泽贤等 5487 & 调查队, 1977 \\
\hline
\end{tabular}


邓双文, 王发国, 刘俊芳, 邢福武. 西沙群岛植物的订正与增补. 生物多样性, 2017, 25 (11): 1246-1250.

http://www.biodiversity-science.net/CN/10.17520/biods.2017066

\begin{tabular}{|c|c|c|c|}
\hline 科名 Family & 物名 Species & 标本 Specimen & 文献 Reference \\
\hline & 海岸桐 Guettarda speciosa L. & 张宏达 4112 & Chang, 1948 \\
\hline & & 西沙队 3201 & \\
\hline & & 西沙队 3371 & \\
\hline & & 李泽贤等 5389 & \\
\hline & 双花耳草 Hedyotis biflora (L.) Lam. & - & 童毅等, 2013 \\
\hline & 伞房花耳草 Hedyotis corymbosa (L.) Lam. & 西沙队 3323 & 广东省植物研究所西沙群岛植物 \\
\hline & & 李泽贤等 5418 & 调查队, 1977 \\
\hline & 海滨木巴戎 Morinda citrifolia L. & 西沙队 3238 & Chang, 1948 \\
\hline & & 李泽贤等 5387 & \\
\hline & 鸡矢藤 Paederia foetida $\mathrm{L}$. & - & 童毅等, 2013 \\
\hline & 墨苜宿 Richardia scabra L. & - & 童毅等, 2013 \\
\hline & 精叶丰花草 Spermacoce hispida L. & 西沙队 3221 & 广东省植物研究所西沙群岛植物 \\
\hline & & 李泽贤等 5504 & 调查队, 1977 \\
\hline & 光叶丰花草 Spermacoce remota Lamarck & 邓双文 170 & 童毅等, 2013 \\
\hline \multirow[t]{20}{*}{ 菊科 Compositae } & 鬼针草 Bidens pilosa $\mathrm{L}$. & 张宏达 4096 & Chang, 1948 \\
\hline & 飞机草 Chromolaena odorata (L.) R. M. King et H. Rob. & 西沙队 3240 & 广东省植物研究所西沙群岛植物 \\
\hline & & 李泽贤等 5391 & 调查队, 1977 \\
\hline & 香丝草 Conyza bonariensis L. & 西沙队 3294 & 广东省植物研究所西沙群岛植物 \\
\hline & & & 调查队, 1977 \\
\hline & 鳢肠 Eclipta prostrata (L.) L. & 西沙队 3218 & 广东省植物研究所西沙群岛植物 \\
\hline & & 李泽贤等 5369 & 调查队, 1977 \\
\hline & 一点红 Emilia sonchifolia (L.) DC. & - & 童毅等, 2013 \\
\hline & 蔓茎栓果菊 Launaea sarmentosa (Willd.) Merr. \& Chun & 西沙队 3318 & 广东省植物研究所西沙群岛植物 \\
\hline & & 李泽贤等 5458 & 调查队, 1977 \\
\hline & 羽芒菊 Tridax procumbens L. & 张宏达 4111 & Chang, 1948 \\
\hline & & 西沙队 3254 & \\
\hline & & 李泽贤等 5416 & \\
\hline & 夜香牛 Vernonia cinerea (L.) Less. & 西沙队 3384 & 广东省植物研究所西沙群岛植物 \\
\hline & & 李泽贤等 5406 & 调查队, 1977 \\
\hline & 咸虾花 Vernonia patula (Dryand.) Merr & 张宏达 4128 & Chang, 1948 \\
\hline & & 西沙队 3401 & \\
\hline & 孪花蟛蜞菊 Wollastonia biflora (L.) DC. & 张宏达 4122 & Chang, 1948 \\
\hline & & 西沙队 3222 & \\
\hline & & 李泽贤等 5498 & \\
\hline \multirow[t]{3}{*}{ 草海桐科 Goodeniaceae } & 草海桐 Scaevola taccada (Gaertn.) Roxb. & 张宏达 4115 & Chang, 1948 \\
\hline & & 西沙队 3237 & \\
\hline & & 李泽贤等 5467 & \\
\hline \multirow[t]{6}{*}{ 紫草科 Boraginaceae } & 橙花破布木 Cordia subcordata Lam. & 西沙队 3216 & 广东省植物研究所西沙群岛植物 \\
\hline & & 李泽贤等 5385 & 调查队, 1977 \\
\hline & 大尾摇 Heliotropium indicum L. & 西沙队 3325 & 广东省植物研究所西沙群岛植物 \\
\hline & & 李泽贤等 5484 & 调查队, 1977 \\
\hline & 银毛树 Tournefortia argentea L. f. & 张宏达 4114 & Chang, 1948 \\
\hline & & 西沙队 3236 & \\
\hline
\end{tabular}


邓双文, 王发国, 刘俊芳, 邢福武. 西沙群岛植物的订正与增补. 生物多样性, 2017, 25 (11): 1246-1250.

http://www.biodiversity-science.net/CN/10.17520/biods.2017066

\begin{tabular}{|c|c|c|c|}
\hline 科名 Family & 物名 Species & 标本 Specimen & 文献 Reference \\
\hline \multirow[t]{8}{*}{ 茄科 Solanaceae } & 洋金花 Datura metel L. & 西沙队 3242 & 广东省植物研究所西沙群岛植物 \\
\hline & & 李泽贤等 5382 & 调查队, 1977 \\
\hline & 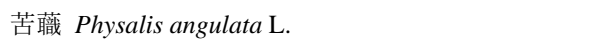 & 西沙队 3203 & 童毅等, 2013 \\
\hline & & 李泽贤等 5403 & \\
\hline & 少花龙葵 Solanum americanum Mill. & 西沙队 3211 & 广东省植物研究所西沙群岛植物 \\
\hline & & 李泽贤等 5376 & 调查队, 1977 \\
\hline & 野茄 Solanum undatum Lam. & 西沙队 3198 & 广东省植物研究所西沙群岛植物 \\
\hline & & & 调查队, 1977 \\
\hline \multirow[t]{19}{*}{ 旋花科 Convolvulaceae } & 土丁桂 Evolvulus alsinoides (L.) L. & 西沙队 3357 & 广东省植物研究所西沙群岛植物 \\
\hline & & & 调查队, 1977 \\
\hline & 猪菜藤 Hewittia malabarica (L.) Suresh & 西沙队 3345 & 广东省植物研究所西沙群岛植物 \\
\hline & & & 调查队, 1977 \\
\hline & 变色牵牛 Ipomoea indica (Burm.) Merr. & 西沙队 3396 & 广东省植物研究所西沙群岛植物 \\
\hline & & & 调查队, 1977 \\
\hline & 牵牛 Ipomoea nil (L.) Roth & 李泽贤等 5496 & 邢福武等, 1993 \\
\hline & 小心叶薯 Ipomoea obscura (L.) Ker Gawl. & 西沙队 3251 & 广东省植物研究所西沙群岛植物 \\
\hline & & 李泽贤等 5494 & 调查队, 1977 \\
\hline & 厚藤 Ipomoea pescaprae (L.) R. Br. & 西沙队 3223 & 广东省植物研究所西沙群岛植物 \\
\hline & & 李泽贤等 5469 & 调查队, 1977 \\
\hline & 虎掌藤 Ipomoea pestigridis L. & 西沙队 3332 & 广东省植物研究所西沙群岛植物 \\
\hline & & & 调查队, 1977 \\
\hline & 羽叶薯 Ipomoea polymorpha Roem. \& Schult. & - & 童毅等, 2013 \\
\hline & 长管车牛 Ipomoea violacea $\mathrm{L}$. & 张宏达 4123 & 广东省植物研究所西沙群岛植物 \\
\hline & & 西沙队 3199 & 调查队, 1977 \\
\hline & & 李泽贤等 5384 & \\
\hline & 小牵牛 Jacquemontia paniculata (Burm. f.) Hall. f. & 西沙队 3320 & 广东省植物研究所西沙群岛植物 \\
\hline & & 李泽贤等 5511 & 调查队, 1977 \\
\hline 玄参科 Scrophulariaceae & 假马齿苋 Bacopa monnieri (L.) Wettst. & 李泽贤等 5527 & 邢福武等, 1993 \\
\hline 爵床科 Acanthaceae & $\begin{array}{l}\text { 小花宽叶十万错 Asystasia gangetica subsp. micrantha } \\
\text { (Nees) Ensermu }\end{array}$ & 邓双文 125 & 新记录 \\
\hline \multirow[t]{11}{*}{ 马鞭草科 Verbenaceae } & 苦郎树 Clerodendrum inerme (L.) Gaertn. & 西沙队 3352 & 广东省植物研究所西沙群岛植物 \\
\hline & & 李泽贤等 5424 & 调查队, 1977 \\
\hline & 过江藤 Phyla nodiflora (L.) Greene & 张宏达 4105 & Chang, 1948 \\
\hline & & 西沙队 3253 & \\
\hline & & 李泽贤等 5429 & \\
\hline & 伞序臭黄荆 Premna serratifolia L. & 张宏达 4127 & Chang, 1948 \\
\hline & & 西沙队 3398 & \\
\hline & & 李泽贤等 5553 & \\
\hline & 假马鞭 Stachytarpheta jamaicensis (L.) Vahl & 西沙队 3255 & 广东省植物研究所西沙群岛植物 \\
\hline & & 李泽贤等 5381 & 调查队, 1977 \\
\hline & 单叶蔓荆 Vitex rotundifolia L. f. & 李泽贤等 5431 & 钟义, 1990 \\
\hline \multirow[t]{2}{*}{ 唇形科 Labiatae } & 山香 Hyptis suaveolens (L.) Poit. & 西沙队 3336 & 广东省植物研究所西沙群岛植物 \\
\hline & & 李泽贤等 5548 & 调查队, 1977 \\
\hline
\end{tabular}


邓双文, 王发国, 刘俊芳, 邢福武. 西沙群岛植物的订正与增补. 生物多样性, 2017, 25 (11): 1246-1250.

http://www.biodiversity-science.net/CN/10.17520/biods.2017066

\begin{tabular}{|c|c|c|c|}
\hline 科名 Family & 物名 Species & 标本 Specimen & 文献 Reference \\
\hline & 蜂巢草 Leucas aspera (Willd.) Link & 西沙队 3276 & 广东省植物研究所西沙群岛植物 \\
\hline & & & 调查队, 1977 \\
\hline & 圣罗勒 Ocimum sanctum L. & 西沙队 3338 & 广东省植物研究所西沙群岛植物 \\
\hline & & & 调查队, 1977 \\
\hline \multirow[t]{2}{*}{ 水鳖科 Hydrocharitaceae } & 喜盐草 Halophila ovalis (R. Br.) Hook. f. & - & 钟义, 1990 \\
\hline & 泰来藻 Thalassia hemprichii (Ehrenb. ex Solms) Asch. & - & 钟义, 1990 \\
\hline \multirow[t]{2}{*}{ 川蔓藻科 Ruppiaceae } & 川蔓藻 Ruppia maritima L. & 西沙队 3364 & 广东省植物研究所西沙群岛植物 \\
\hline & & & 调查队, 1977 \\
\hline \multirow[t]{2}{*}{ 茨藻科 Najadaceae } & 草茨藻 Najas graminea Delile & 西沙队 3396 & 广东省植物研究所西沙群岛植物 \\
\hline & & & 调查队, 1977 \\
\hline \multirow[t]{3}{*}{ 鸭跖草科 Commelinaceae } & 饭包草 Commelina benghalensis L. & 西沙队 3322 & 广东省植物研究所西沙群岛植物 \\
\hline & & & 调查队, 1977 \\
\hline & 节节草 Commelina diffusa Burm. f. & 李泽贤等 5542 & 邢福武等, 1993 \\
\hline \multirow[t]{2}{*}{ 露兒树科 Pandanaceae } & 露兒树 Pandanus tectorius Parkinson & 西沙队 3313 & 广东省植物研究所西沙群岛植物 \\
\hline & & 李泽贤等 5442 & 调查队, 1977 \\
\hline 兰科 Orchidaceae & 美冠兰 Eulophia graminea Lindl. & 李泽贤等 5378 & 邢福武等, 1993 \\
\hline \multirow[t]{23}{*}{ 莎草科 Cyperaceae } & 扁穗莎草 Cyperus compressus L. & 西沙队 3324 & 广东省植物研究所西沙群岛植物 \\
\hline & & & 调查队, 1977 \\
\hline & 砖子苗 Cyperus cyperoides (L.) Kuntze & 西沙队 3345 & 广东省植物研究所西沙群岛植物 \\
\hline & & & 调查队, 1977 \\
\hline & 疏穗莎草 Cyperus distans L.f. & 西沙队 3341 & 广东省植物研究所西沙群岛植物 \\
\hline & & & 调查队, 1977 \\
\hline & 羽状穗砖子苗 Cyperus javanicus Houtt. & 西沙队 3224 & 广东省植物研究所西沙群岛植物 \\
\hline & & 李泽贤等 5372 & 调查队, 1977 \\
\hline & 香附子 Cyperus rotundus L. & 西沙队 3225 & 广东省植物研究所西沙群岛植物 \\
\hline & & & 调查队, 1977 \\
\hline & 粗根茎莎草 Cyperus stolonifer Retz. & 西沙队 3284 & 广东省植物研究所西沙群岛植物 \\
\hline & & 李泽贤等 5485 & 调查队, 1977 \\
\hline & 佛艳苍飘拂草 Fimbristylis spathacea Roth & 西沙队 3347 & 邢福武等, 1993 \\
\hline & & 李泽贤等 5462 & \\
\hline & & 李泽贤等 5468 & \\
\hline & 锈鳞飘拂草 Fimbristylis sieboldii Miq. ex Franch. \& Sav. & 西沙队 3283 & 广东省植物研究所西沙群岛植物 \\
\hline & & 李泽贤等 5493 & 调查队, 1977 \\
\hline & 双穗飘拂草 Fimbristylis subbispicata Nees \& Meyen & - & 钟义, 1990 \\
\hline & 短叶水蜈蚣 Kyllinga brevifolia Rottb. & 西沙队 3213 & 广东省植物研究所西沙群岛植物 \\
\hline & & & 调查队, 1977 \\
\hline & 多枝扁莎 Pycreus polystachyos (Rottb.) P. Beauv. & 西沙队 3315 & 广东省植物研究所西沙群岛植物 \\
\hline & & 西沙队 3340 & 调查队, 1977 \\
\hline & & 李泽贤等 5482 & \\
\hline \multirow[t]{4}{*}{ 禾本科 Gramineae } & 臭根子草 Bothriochloa bladhii (Retz.) S. T. Blake & 西沙队 3314 & 广东省植物研究所西沙群岛植物 \\
\hline & & 李泽贤等 5549 & 调查队, 1977 \\
\hline & 四生臂形草 Brachiaria subquadripara (Trin.) Hitchc. & 西沙队 3206 & 广东省植物研究所西沙群岛植物 \\
\hline & & 李泽贤等 5410 & 调查队, 1977 \\
\hline
\end{tabular}


邓双文, 王发国, 刘俊芳, 邢福武. 西沙群岛植物的订正与增补. 生物多样性, 2017, 25 (11): 1246-1250.

http://www.biodiversity-science.net/CN/10.17520/biods.2017066

\begin{tabular}{|c|c|c|c|}
\hline \multirow[t]{2}{*}{ 科名 Family } & 物名 Species & 标本 Specimen & 文献 Reference \\
\hline & & 李泽贤等 5524 & \\
\hline & 毛臂形草 Brachiaria villosa (Lam.) A. Camus & 西沙队 3296 & 新记录 \\
\hline & 孟仁草 Chloris barbata Sw. & 李泽贤等 5473 & 广东省植物研究所西沙群岛植物 \\
\hline & & & 调查队, 1977 \\
\hline & 台湾虎尾草 Chloris formosana (Honda) Keng ex B. S. & 西沙队 3383 & 钟义, 1990 \\
\hline & Sun \& Z. H. Hu & & \\
\hline & 狗牙根 Cynodon dactylon (L.) Pers. & 西沙队 3277 & 广东省植物研究所西沙群岛植物 \\
\hline & & 西沙队 3330 & 调查队, 1977 \\
\hline & & 李泽贤等 5471 & \\
\hline & 弯穗狗牙根 Cynodon radiatus Roth & 西沙队 3375 & 广东省植物研究所西沙群岛植物 \\
\hline & & & 调查队, 1977 \\
\hline & 龙爪茅 Dactyloctenium aegyptium (L.) Beauv. & 西沙队 3205 & 广东省植物研究所西沙群岛植物 \\
\hline & & 西沙队 3367 & 调查队, 1977 \\
\hline & 双花草 Dichanthium annulatum (Forssk.) Stapf & - & 钟义, 1990 \\
\hline & 升马唐 Digitaria ciliaris (Retz.) Koeler & 西沙队 3215 & 广东省植物研究所西沙群岛植物 \\
\hline & & 西沙队 3233 & 调查队, 1977 \\
\hline & & 西沙队 3377 & \\
\hline & & 李泽贤等 5497 & \\
\hline & 二型马唐 Digitaria heterantha (Hook. f.) Merr. & 李泽贤等 5523 & 广东省植物研究所西沙群岛植物 \\
\hline & & & 调查队, 1977 \\
\hline & 红尾翎 Digitaria radicosa (J. Presl) Miq. & 邓双文 162 & 邢福武, 1993 \\
\hline & 马唐 Digitaria sanguinalis (L.) Scopoli & 李泽贤等 5409 & Chang, 1948 \\
\hline & 海南马唐 Digitaria setigera Roth & 西沙队 3247 & 广东省植物研究所西沙群岛植物 \\
\hline & & 西沙队 3339 & 调查队, 1977 \\
\hline & & 李泽贤等 5543 & \\
\hline & 长画眉草 Eragrostis brownii (Kunth) Nees & 李泽贤等 5522 & 邢福武等, 1993 \\
\hline & 牛筋草 Eleusine indica (L.) Gaertn. & 西沙队 3248 & 广东省植物研究所西沙群岛植物 \\
\hline & & 李泽贤等 5407 & 调查队, 1977 \\
\hline & 鲫鱼草 Eragrostis tenella (L.) P. Beauv. ex Roem. \& & 张宏达 4102 & 钟义, 1990 \\
\hline & Schult. & 西沙队 3214 & \\
\hline & & 李泽贤等 5370 & \\
\hline & 高野㯟 Eriochloa procera (Retz.) C. E. Hubb. & 西沙队 3202 & 广东省植物研究所西沙群岛植物 \\
\hline & & 西沙队 3316 & 调查队, 1977 \\
\hline & 黄茅 Heteropogon contortus (L.) P. Beauv. ex Roem. \& & 李泽贤等 5476 & 钟义, 1990 \\
\hline & Schult. & & \\
\hline & 白茅 Imperata cylindrica (L.) Raeusch. var. major (Nees) & - & 钟义, 1990 \\
\hline & C. E. Hubb. & & \\
\hline & 千金子 Leptochloa chinensis (L.) Nees & - & 钟义, 1990 \\
\hline & 细穗草 Lepturus repens (G. Forst.) R. Br. & - & 邢福武等, 1993 \\
\hline & 红毛草 Melinis repens (Willd.) Zizka & 李泽贤等 5404 & 邢福武等, 1993 \\
\hline & 芒 Miscanthus sinensis Andersson & - & 钟义, 1990 \\
\hline & 蛇尾草 Ophiuros exaltatus (L.) Kuntze. & - & 童毅等, 2013 \\
\hline & 铺地㯟 Panicum repens L. & 西沙队 3246 & 广东省植物研究所西沙群岛植物 \\
\hline
\end{tabular}


邓双文, 王发国, 刘俊芳, 邢福武. 西沙群岛植物的订正与增补. 生物多样性, 2017, 25 (11): 1246-1250.

http://www.biodiversity-science.net/CN/10.17520/biods.2017066

\begin{tabular}{|c|c|c|c|}
\hline 科名 Family & 物名 Species & 标本 Specimen & 文献 Reference \\
\hline & \multirow{3}{*}{ 双穗雀稗 Paspalum distichum L. } & & 调查队, 1977 \\
\hline & & 西沙队 3282 & 广东省植物研究所西沙群岛植物 \\
\hline & & 李泽贤等 5534 & 调查队, 1977 \\
\hline & 圆果雀稗 Paspalum scrobiculatum L. var. orbiculare (G. & 西沙队 3295 & 邢福武等, 1993 \\
\hline & Forst.) Hack. & 李泽贤等 5477 & \\
\hline & 茅根 Perotis indica (L.) Kuntze & 李泽贤等 5516 & 邢福武等, 1993 \\
\hline & 筒轴茅 Rottboellia cochinchinensis (Lour.) Clayton & - & 钟义, 1990 \\
\hline & \multirow[t]{2}{*}{ 斑茅 Saccharum arundinaceum Retz. } & 西沙队 3386 & 广东省植物研究所西沙群岛植物 \\
\hline & & & 调查队, 1977 \\
\hline & \multirow[t]{2}{*}{ 鼠尾粟 Sporobolus fertilis (Steud.) Clayton } & \multirow[t]{2}{*}{ 西沙队 3337} & 广东省植物研究所西沙群岛植物 \\
\hline & & & 调查队, 1977 \\
\hline & \multirow[t]{2}{*}{ 盐地鼠尾粟 Sporobolus virginicus (L.) Kunth } & 西沙队 3298 & 广东省植物研究所西沙群岛植物 \\
\hline & & 李泽贤等 5441 & 调查队, 1977 \\
\hline & 雉穗钝叶草 Stenotaphrum micranthum (Desv.) C. E. & 西沙队 3299 & 广东省植物研究所西沙群岛植物 \\
\hline & Hubb. & 李泽贤等 5450 & 调查队, 1977 \\
\hline & 葛雷草 Thuarea involuta (G. Forst.) R. Br. ex Roem. \& & 西沙队 3204 & Chang, 1948 \\
\hline & Schult. & 李泽贤等 5456 & \\
\hline
\end{tabular}

\section{参考文献}

Chang HT (1948) The vegetation of the Paracel

Islands. Sunyatsenia, 7(1-2), 75-88.

Paracel Islands Plant Expedition of Guangdong Institute of Botany (1977) Plants and Vegetation on Xisha Islands of China. Science Press, Beijing. (in Chinese) [广东省植物研究所西沙群岛植物调查 队 (1977) 中国西沙群岛的植物和植被. 科学出 版社, 北京.]

Tong Y, Jian SG, Chen Q, Li YL, Xing FW (2013)

Vascular plant diversity of the Paracel Islands,

China. Biodiversity Science, 21, 364-374. (in

Chinese with English abstract) [童毅，简曙光，陈 权, 李玉玲, 邢福武 (2013) 中国西沙群岛植物 多样性. 生物多样性, 21, 364-374.]

Xing FW, Wu DL (1996) Flora of Nansha Islands and Their Neighbouring Islands. China Ocean Press, Beijing. (in Chinese) [邢福武, 吴德邻 (1996) 南 沙群岛及其邻近岛屿植物志. 海洋出版社, 北 京. ]

Xing FW, Wu DL, Li ZX, Ye HG, Chen BH (1993) Investigation of plant resources in Xisha Islands. Journal of Plant Resources and Environment, 2(3), 1-6. (in Chinese with English abstract) [邢福武,
吴德邻, 李泽贤, 叶华谷, 陈㶧辉 (1993) 西沙 群岛植物资源调查. 植物资源与环境, 2(3), 1-6.]

Zhong Y (1990) The plant resources investigation of Paracel Islands, Hainan. Journal of Hainan Normal University, 3(1), 48-65. (in Chinese with English abstract) [钟义 (1990) 海南省西沙群岛植物资源 考察. 海南师范学院学报, 3(1), 48-65.] 
邓双文, 王发国, 刘俊芳, 邢福武. 西沙群岛植物的订正与增补. 生物多样性, 2017, 25 (11): 1246-1250.

http://www.biodiversity-science.net/CN/10.17520/biods.2017066

\section{附录2 西沙群岛增补及订正植物种类的描述}

2

4

8

10

12

14

16

18

20

22

24

26

28

30

32

34

36

38

40

42

Appendix 2 Description of plants supplemented and revised of Xisha Islands, China

1 分类群增补

(1)匍匐黄细心(紫茉莉科 Nyctaginaceae)

Boerhavia repens L., Sp. Pl. 1: 3. 1753; Fl. China 5: 433-434. 2003.

东岛, 海拔 3 m, 海边灌从旁, 邓双文 95 (IBSC), 2016-06-06。

主要特征: 草本, 全株近肉质。茎平卧, 先端稍上升, 无毛。聚伞花序腋生, 总花梗长; 花 冠多为白色。掺花果棍棒状, 具 5 棱, 具粘腺。

分布: 浙江、福建、广东; 广布于非洲、美洲和亚洲; 生于海边干旱处。

该种以叶缘不具多细胞毛, 花具梗, 花冠白色区别于黄细心(B. diffusa L.)。

(2)小刀豆(蝶形花科 Papilionaceae)

Canavalia cathartica Thou., J. Bot. Agric. 1: 81. 1813; Fl. China 10: 198-199. 2010.

东岛，海拔 $2 \mathrm{~m}$, 生于海边林缘灌从，邓双文 109 (IBSC), 2016-06-06。

主要特征: 匍匐或攀缘藤本。小叶先端急尖或圆, 不微凹。荚果长 7-9 cm。种子长 $1.8 \mathrm{~cm}$ 。

分布: 广东、海南、台湾; 广布于亚洲，非洲生于海滨，常攀缘于灌木上。

该种与海刀豆(C. maritima (Sw.) DC.)生境相同, 形态相似。小刀豆以小叶先端不微凹, 荚 果较短, 种子较长而区别于后者。

(3)落地豆(蝶形花科 Papilionaceae)

20 Rothia indica (L.) Druce, Bot. Exch. Club Soc. Brit. Isles 3: 423. 1914; Fl. China 10: 118. 2010.

22 永兴岛, 海拔 $3 \mathrm{~m}$, 路边草地, 邓双文 131(IBSC), 2016-12-23。

主要特征: 草本。茎多分枝, 披散, 被毛。掌状复叶具 3 小叶, 全缘, 被绢毛。花序与叶对 生, 有花 1-3 朵, 黄色。荚果线形, 被绢毛, 无间隔。

分布: 广东南部、海南; 分布于东南亚及澳洲北部，常生于近海沙地，少见。

(4)矮灰毛豆(蝶形花科 Papilionaceae)

Tephrosia pumila (Lam.) Pers., Syn. Pl. 2(2): 330. 1807; Fl. China 10: 190-193. 2010.

永兴岛, 海拔 $3 \mathrm{~m}$, 路边草地, 邓双文 119 (IBSC), 2016-12-23。

主要特征: 草本。茎披散, 密被毛。小叶常 3-5 对, 两面被毛。花序有花约 3 朵, 白色、

淡黄色或淡红色。荚果先端具下弯钩潒。种子约 9 粒。

分布: 海南沿海; 热带非洲、热带亚洲及澳洲北部, 喜生与海边岩石上。

(5)小花宽叶十万错(爵床科 Acanthaceae)

Asystasia gangetica subsp. micrantha (Nees) Ensermu, Proc. XIII Plen. Meet. AETFAT Zomba Malawi: 1: 343. 1994; Fl. China 19: 437-438. 2011.

永兴岛, 海拔 3 m, 路边草地, 邓双文 125 (IBSC), 2016-12-23。

主要特征: 草本。叶对生, 基部钝, 圆或近心形。花冠较小, 白色, 下唇中裂片具紫斑。

分布: 广东、海南、台湾; 非洲、亚洲西南部、印度洋岛屿、马达加斯加, 生于林缘, 路 边(图 1M, N, O)。

2 分类群学名订正

(1)皱果苋

Amaranthus viridis L.—A. caudatus auct. non L.: 我国西沙群岛的植物和植被: 78. 1977.

珊瑚岛, 平地沙土, 西沙队 3363(IBSC), 1974-07-11。 
邓双文, 王发国, 刘俊芳, 邢福武. 西沙群岛植物的订正与增补. 生物多样性, 2017, 25 (11): 1246-1250.

http://www.biodiversity-science.net/CN/10.17520/biods.2017066

皱果苋与尾穗苋(A. caudatus L.)的区别在于前者叶长 3-9 cm, 圆雉花序较小, 长 6-12 cm,

44

46

48

50

52

54

56

58

60

62

64

66

68

70

72

74

76

78

80

82

84

西沙队 3363 号标本叶长约 $5 \mathrm{~cm}$, 花序长约 $8 \mathrm{~cm}$, 应为皱果苋。

\section{(2)黄细心}

Boerhavia diffusa L.—B. chinensis auct. non (L.) Rottb.: 我国西沙群岛的植物和植被: 78-79. 1977.

5 永兴岛, 平地路旁, 西沙队 3260(IBSC), 1974-06-20。

黄细心与华黄细心(B. chinensis (L.) Rottb.)的区别在于前者叶片卵形，叶缘具显著长毛， 聚伞圆雉花序; 后者叶片三角状卵形或心状卵形, 叶缘无毛, 伞形花序。

西沙队 3260 号标本叶缘具毛, 聚伞圆雉花序, 应为黄细心; 鲁德全鉴定该号标本为黄细 心, 鉴定准确。

(3)匍匐黄细心

Boerhavia repens L.—B. diffusa auct. non L.: H. T. Chang in Sunyatsenia, 7(1-2), 80-81. 1948; 我国西沙群岛的植物和植被: 78-79. 1977.

东岛, 沙地, 张宏达 4113(IBSC), 1947-04-22。

永兴岛，沙土，西沙队 3210(IBSC), 1974-06-19。

匍匐黄细心与黄细心 (B. diffusa L.) 的区别在于前者茎匍匐, 先端上升, 叶缘无毛, 花序腋 生, 常 5 朵花组成伞形花序, 有时再组成聚伞圆雉花序; 后者茎直立, 叶缘具显著长毛, 花序 顶生，聚伞圆锥花序。

上述两号标本匍匐或半直立(见标本采集记录), 叶缘无毛, 花序腋生, 应为匍匐黄细心。

(4)圆叶黄花稔

Sida alnifolia var. orbiculata S. Y. Hu-S. chinensis auct. non Retz.: F. W. Xing et al in J. Plant Resour. Environ. 2(3), 4. 1993.-S. parvifolia auct. non DC.: 我国西沙群岛的植物和植被: 68, 84. 1977.

永兴岛, 李泽贤、邢福武 5489(IBSC), 1992-05-25。

永兴岛, 平地路旁, 西沙队 3259(IBSC), 1974-06-20。

圆叶黄花稔与中华黄花稔(S. chinensis Retz.)的区别在于前者叶为圆形, 叶两面密被短毛, 花柄长达 $3 \mathrm{~cm}$ ，后者叶多为倒卵形或椭圆形，叶上面无毛或被疏毛，花柄长约 $1 \mathrm{~cm}$ 。

李泽贤、邢福武 5489 号标本, 叶近圆形, 两面被毛, 花梗长约 $2 \mathrm{~cm}$, 应为圆叶黄花稔。

S. alnifolia var. orbiculata 和 S. parvifolia 的中文名均为圆叶黄花稔, 然而两者形态差异很 大, 前者叶大, 圆形, 长 $2 \mathrm{~cm}$, 花梗长达 $3.5 \mathrm{~cm}$; 后者叶极小, 椭圆形, 长不及 $1 \mathrm{~cm}$, 花梗长约 $1 \mathrm{~cm}$ 。

西沙队 3259 号标本, 叶较大, 圆形, 花梗长, 应为 S. alnifolia var. orbiculata。

\section{(5)长梗黄花稔}

Sida cordata (Burm. f.) Borss.—S. mysorensis auct. non Wight et Arn.: 我国西沙群岛的植 物和植被: 84. 1977.

永兴岛、平地、路旁、沙土、疏林，西沙队 3230(IBSC), 1974-06-20。

长梗黄花稔与粘毛黄花稔(S. mysorensis Wight et Arn.) 叶均为心形, 区别在于前者枝条叶 柄被长柔毛, 花单生于叶腋, 花梗长约 2-4 cm; 后者枝密被腺毛, 花组成密集的总状花序生于 叶腋, 花梗短于 $1 \mathrm{~cm}$ 。

西沙队 3230 号标本枝条无腺毛, 花单生叶腋, 花梗长约 $2 \mathrm{~cm}$, 为长梗黄花稔。

(6)猩猩草 
邓双文, 王发国, 刘俊芳, 邢福武. 西沙群岛植物的订正与增补. 生物多样性, 2017, 25 (11): 1246-1250.

http://www.biodiversity-science.net/CN/10.17520/biods.2017066

86

88

90

92

94

96

98

100

102

104

106

108

110

112

114

116

118

120

122

124

126

128

Euphorbia cyathophora Murr.-E. heterophylla auct. non L.: 我国西沙群岛的植物和植被: 84-85. 1977.

东岛，平地、沙土，西沙队 3397(IBSC), 1974-09-29。

永兴岛, 李泽贤、邢福武 5400(IBSC), 1992-05-21。

猩猩草与白苞猩猩草(E. heterophylla L.) 的区别在于前者叶常为提琴状，叶状苞片椭圆形, 下半部红色; 后者通常为长椭圆形, 全缘, 叶状苞片长条形, 下半部白色。

上述两号标本叶为提琴状、叶状苞片椭圆形，应为猩猩草。

(7)匍匐大戟

Euphorbia prostrata Aiton-E. heyneana auct. non Spreng.: H. T. Chang in Sunyatsenia, 7(1-2), 82. 1948.

6 东岛, 路旁、无阴, 张宏达 4098(IBSC), 1947-04-22。

匍匐大戟与小叶地锦(E. heyneana Spreng.)的区别在于前者果实在棱上有毛，后者果实光 滑无毛。

张宏达 4098 号标本原鉴定为 E. microphylla B. Heyne ex Roth, 为小叶地锦(E. heyneana)的 异名; 该标本果实棱上有毛，应为匍匐大戟; 丘华兴鉴定该号标本为匍匐大戟，鉴定准确。

(8)苦味叶下珠

Phyllanthus amarus Schumach. et Thonn.-P. urinaria auct. non L.: H. T. Chang in Sunyatsenia, 7(1-2), 82. 1948.

东岛、草地，张宏达 4120(IBSC), 1947-04-26。

苦味叶下珠与叶下珠(P. urinaria L.)的区别在于前者植株较高, 茎下部常木质化, 叶较小, 蒴果表面光滑; 后者植株矮小, 不木质化，叶较大，蒴果表面具病点。

张宏达 4120 号标本植株大，叶较小，蒴果光滑，应为苦味叶下珠; 丘华兴鉴定该标本为苦 味叶下珠, 鉴定准确。

(9)刺果苏木

Caesalpinia bonduc (L.) Roxb. C C. minax auct. non Hance: 我国西沙群岛的植物和植被: 88. 1977.

金银岛, 平地, 西沙队 3366(IBSC), 1974-07-20。

刺果苏木与嗀荚云实(C. minax Hance)的区别在于前者托叶大，叶状，后者托叶小，雉状。

西沙队 3366 号标本, 托叶大, 叶状, 应为刺果苏木; 李仕晋鉴定该标本为刺果苏木, 鉴定 准确。

(10)海刀豆

Canavalia rosea (Sw.) DC.—Mucuna hainanensis auct. non Hayata: 我国西沙群岛的植物 和植被: 90. 1977.

永兴岛，海边沙土，西沙队 3405(IBSC), 1974-07-28。

该号标本为小苗, 生于海边沙土, 根据其生境且西沙群岛多次调查均无海南黧豆(Mucuna hainanensis Hayata)记录判断，该标本应为海刀豆。

\section{(11)笔管榕}

Ficus subpisocarpa Gagnep.-F. virens auct. non Aiton: 我国西沙群岛的植物和植被: 92. 1977.

永兴岛，平地、疏林、肥土、沙土，西沙队 3234(IBSC), 1974-06-20。

永兴岛，李泽贤、邢福武 5474, 1992-05-25。

笔管榕与黄葛树 (F. virens Aiton)的区别在于前者叶为三出脉, 隐头花序具总梗; 后者叶为 羽状脉，隐头花序无总梗。

上述两号标本，叶脉为三出脉，花序梗明显，应为笔管榕。 
邓双文, 王发国, 刘俊芳, 邢福武. 西沙群岛植物的订正与增补. 生物多样性, 2017, 25 (11): 1246-1250.

http://www.biodiversity-science.net/CN/10.17520/biods.2017066

130

132

134

136

138

140

142

144

146

148

150

152

154

156

158

160

162

164

166

168

170

172

(12)光叶丰花草

Spermacoce remota Lam._- S. pusilla auct. non Wall.: Y. Tong in Biodivers. Sci., Appendix 1: 9. 2013.

永兴岛，林缘，邓双文 170(IBSC), 2016-12-23。

光叶丰花草与丰花草(S. pusilla Wall.)的区别在于前者叶狭栯圆形至披针形，宽 4-16 mm; 后者叶线状长圆形, 宽 4-6 mm。

根据实地调查, 名录中记录之丰花草应为光叶丰花草。

(13)海人树

Suriana maritima L.—Scaevola hainanensis auct. non Hance: H. T. Chang in Sunyatsenia, 7(1-2), 84. 1948.

东岛，海边，张宏达 4119(SYS), 1947-04-26。

海人树植物密被柔毛, 叶聚生于枝顶, 子房上位, 心皮离生。而小草海桐(Scaevola hainanensis Hance)叶肉质，常 2 枚生于同一节点，植株无毛，子房下位，核果。

张宏达 4119 号标本枝、叶密被柔毛, 叶聚生枝顶, 果萝宿存, 被毛, 子房上位, 应为海人 树，原误定为小草海桐。

\section{(14)苦蘵}

Physalis angulata L.—P. minima auct. non L.: 我国西沙群岛的植物和植被: 98. 1977。

永兴岛, 平地、沙土，西沙队 3203(IBSC), 1974-06-19。

永兴岛, 李泽贤、邢福武 5403, 1992-05-21。

苦蘵与小酸浆 (P. minima L.) 的区别在于前者植株粗壮, 花药紫色, 果梗长约 $2 \mathrm{~cm}$, 果实直

径为 1.5-2.5 cm; 后者植株较小、花药黄色, 果梗长不及 $1 \mathrm{~cm}$, 果实直径为 1-1.5 $(-2) \mathrm{cm}$ 。

西沙队 3203 号标本, 果梗长 $2 \mathrm{~cm}$, 花药紫色, 果实直径 $2.2 \mathrm{~cm}$; 李泽贤、邢福武 5403 号 标本, 植株高大, 茎粗。上述两号标本应为苦蘵。

(15)管花薯

Ipomoea violacea L.—I. alba auct. non L.: H. T. Chang in Sunyatsenia, 7(1-2), 85-86. 1948. 东岛, 灌木林中, 张宏达 4123(IBSC), 1947-04-26。

管花薯与月光花(I. alba L.) 叶形相似, 花冠均具长花冠管, 的区别在于前者雄荵内藏, 蒴 果近球形, 先端圆; 后者雄荵伸出, 蒴果卵形, 具锐尖头。

张宏达 4123 号标本, 蒴果近球形, 先端圆, 应为管花薯; 丘华兴鉴定该标本为管花薯, 鉴 定准确。

\section{(16)蜂巢草}

Leucas aspera (Willd.) Link-L. zeylanica auct. non (L.) R. Brown: 我国西沙群岛的植物 和植被: 102. 1977.

永兴岛, 平地、沙土，西沙队 3276(IBSC), 1974-06-21。

蜂巢草与绉面草(L. zeylanica (L.) R. Brown)的区别在于前者轮伞花序大, 直径 2-2.5 cm, 多花, 苍片与花蔩等长; 后者轮伞花系小, 直径 $1.5 \mathrm{~cm}$, 少花, 苍片较花蔩短。

6 西沙队 3276 号标本轮伞花序直径为 $2.5 \mathrm{~cm}$, 花 20 余朵, 苞片与花莕等长, 应为蜂巢草。

\section{(17)佛焰苞飘拂草}

Fimbristylis spathacea Roth—F. dichotoma auct. non (L.) Vahl: 我国西沙群岛的植物和植 被: 106. 1977.

永兴岛，平地、沙土，西沙队 3347(IBSC), 1974-07-02。

佛艳苞飘拂草与两歧飘拂草(F. dichotoma (L.) Vahl)的区别在于前者总苞片 1-3 枚, 远短于 花序, 花序小且紧密, 伞梗短, 长不超过 $3 \mathrm{~cm}$, 小穗单生或少数族生; 后者总苍片 3-4 枚, 其中 两枚长于花序, 花序大而开展, 伞梗长达 $10 \mathrm{~cm}$, 小穗单生。 
邓双文, 王发国, 刘俊芳, 邢福武. 西沙群岛植物的订正与增补. 生物多样性, 2017, 25 (11): 1246-1250.

http://www.biodiversity-science.net/CN/10.17520/biods.2017066

174

176

178

180

182

184

186

188

190

192

194

196

198

200

202

204

206

208

210

212

214

216

西沙队 3347 号标本，总苍片短，长约 $1 \mathrm{~cm}$ ，花序紧密，伞梗短，应为佛焰苍飘拂草。

(18)龙爪茅

Dactyloctenium aegyptium (L.) Willd._-Arthraxon hispidus var. cryptatherus auct. non (Hack.) Honda: 我国西沙群岛的植物和植被: 106. 1977.

金银岛, 平地、沙土，西沙队 3367(IBSC), 1974-07-12。

龙爪茅与匿芒荩草(Arthraxon hispidus var. cryptatherus (Hack.) Honda)的区别在于前者植 株基部横卧地面, 叶片长披针形, 基部不完全抱茎, 两面被病基毛, 叶鞘常松弛; 后者植株直 立，叶片卵状披针形，基部心形，抱茎，除下部边缘生病基毛外余均无毛，叶鞘紧密包裹于茎。 西沙队 3367 号标本叶形、叶鞘、毛被均符合龙爪茅之特征，应为龙爪茅。

(19)毛臂形草

Brachiaria villosa (Lam.) A. Camus-B. ramosa auct. non (L.) Stapf: 我国西沙群岛的植 物和植被: 108. 1977 。

永兴岛, 平地, 西沙队 3296(IBSC), 1974-06-21。

毛臂形草与多枝臂形草(B. ramosa (L.) Stapf)的区别在于前者小穗单生，小穗柄短; 后者小 穗成对着生, 一有柄, 一无柄。

该号标本小穗单生，有毛，形态符合毛臂形草特征，原误定为多枝臂形草。

(20)狗牙根

Cynodon dactylon (L.) Pers.—Eremochloa ophiuroides auct. non (Munro) Hack.: 我国西沙 群岛的植物和植被: 108. 1977.

永兴岛, 平地、沙土，西沙队 3330(IBSC), 1974-06-24。

狗牙根与假俭草(Eremochloa ophiuroides (Munro) Hack.)植株匍匐, 营养器官形态较为相 似, 区别在于前者叶片线形, 质软, 先端尖, 叶鞘鞘口常具柔毛, 叶舌为一轮纤毛; 后者叶片 质硬, 纵脉明显, 叶先端较钝, 叶舌毛较少。

西沙队 3330 号标本形态符合狗牙根的特征, 原误定为假俭草。

(21)鲫鱼草

Eragrostis tenella (L.) Beauv. ex Roem. et Schult.——E. amabilis auct. non (L.) Wight \& Arn.: H. T. Chang in Sunyatsenia, 7(1-2), 85-86. 1948.—E. ciliata auct. non (Roxb.) Nees: 我国西沙 群岛的植物和植被: 110.1977.

东岛、海滨、沙地, 张宏达 4102(IBSC), 1947-04-22。

永兴岛，李泽贤、邢福武 5370(IBSC), 1992-05-21。

永兴岛, 平地、沙土，西沙队 3214(IBSC), 1974-06-19。

上述两号标本原鉴定为南部知风草(E. amabilis (L.) Wight \& Arn.), 后 FOC 将南部知风草 作为牛䖝草(E. unioloides (Retz.) Nees ex Steud.)的异名, 童毅(2013)名录中据此将南部知风草 修订为牛䖝草。

鲫鱼草与牛䖝草的区别在于前者植株基部分枝较多，叶较长，圆雉花序分枝 3-4 次，小穗 长 $2 \mathrm{~mm}$; 后者植株基部分枝较少，叶较短，圆雉花序分枝 2 次，小穗长约 $4 \mathrm{~mm}$ 。

张宏达 4102 号和李泽贤、邢福武 5370 号标本形态符合鲫鱼草的特征, 应为鲫鱼草。

鲫鱼草与纤毛画眉草(E. ciliate (Roxb.) Nees)的区别在于前者圆雉花序开展; 后者圆雉花 序紧缩成穗状, 圆柱形。

西沙队 3214 号标本形态符合鲫鱼草的特征, 应为鲫鱼草。

(22)圆果雀稗

Paspalum scrobiculatum var. orbiculare (G. Forst.) Hack.—P. longifolium auct. non Roxb.: 我国西沙群岛的植物和植被: 110. 1977.

永兴岛，平地、沙土，西沙队 3295(IBSC), 1974-06-21。 
邓双文, 王发国, 刘俊芳, 邢福武. 西沙群岛植物的订正与增补. 生物多样性, 2017, 25 (11): 1246-1250.

http://www.biodiversity-science.net/CN/10.17520/biods.2017066

圆果雀稗与长叶雀稗(P. longifolium Roxb.)的区别在于前者小穗单生，在穗轴上排列成 2 行; 后者小穗孪生, 在穗轴上排列成 4 行。 